\title{
Transcriptome resources and functional characterization of monoterpene synthases for two host species of the mountain pine beetle, lodgepole pine (Pinus contorta) and jack pine (Pinus banksiana)
}

Dawn E Hall', Macaire M S Yuen ${ }^{1}$, Sharon Jancsik ${ }^{1}$, Alfonso Lara Quesada ${ }^{1}$, Harpreet K Dullat ${ }^{1}$, Maria Li', Hannah Henderson ${ }^{1}$, Adriana Arango-Velez ${ }^{2}$, Nancy Y Liao ${ }^{3}$, Roderick T Docking ${ }^{3}$, Simon K Chan ${ }^{3}$, Janice EK Cooke ${ }^{2}$, Colette Breuil ${ }^{4}$, Steven JM Jones ${ }^{3}$, Christopher I Keeling ${ }^{1}$ and Jörg Bohlmann ${ }^{1 *}$

\begin{abstract}
Background: The mountain pine beetle (MPB, Dendroctonus ponderosae) epidemic has affected lodgepole pine (Pinus contorta) across an area of more than 18 million hectares of pine forests in western Canada, and is a threat to the boreal jack pine (Pinus banksiana) forest. Defence of pines against MPB and associated fungal pathogens, as well as other pests, involves oleoresin monoterpenes, which are biosynthesized by families of terpene synthases (TPSs). Volatile monoterpenes also serve as host recognition cues for MPB and as precursors for MPB pheromones. The genes responsible for terpene biosynthesis in jack pine and lodgepole pine were previously unknown.

Results: We report the generation and quality assessment of assembled transcriptome resources for lodgepole pine and jack pine using Sanger, Roche 454, and Illumina sequencing technologies. Assemblies revealed transcripts for approximately 20,000 - 30,000 genes from each species and assembly analyses led to the identification of candidate full-length prenyl transferase, TPS, and P450 genes of oleoresin biosynthesis. We cloned and functionally characterized, via expression of recombinant proteins in E. coli, nine different jack pine and eight different lodgepole pine mono-TPSs. The newly identified lodgepole pine and jack pine mono-TPSs include (+)-a-pinene synthases, (-)-a-pinene synthases, (-)- $\beta$-pinene synthases, (+)-3-carene synthases, and (-)- $\beta$-phellandrene synthases from each of the two species.
\end{abstract}

Conclusion: In the absence of genome sequences, transcriptome assemblies are important for defence gene discovery in lodgepole pine and jack pine, as demonstrated here for the terpenoid pathway genes. The product profiles of the functionally annotated mono-TPSs described here can account for the major monoterpene metabolites identified in lodgepole pine and jack pine.

Keywords: Conifer defence, Pine oleoresin, Terpenoid biosynthesis, Metabolite profile, Prenyl transferase, Cytochrome P450, Conifer genome

\footnotetext{
* Correspondence: bohlmann@msl.ubc.ca

${ }^{1}$ Michael Smith Laboratories, University of British Columbia, 2185 East Mall,

Vancouver, British Columbia V6T 1Z4, Canada

Full list of author information is available at the end of the article
} 


\section{Background}

The mountain pine beetle (MPB; Dendroctonus ponderosae Hopkins) epidemic has affected an area of more than 18 million hectares of lodgepole pine (Pinus contorta Douglas) in western Canada [1,2]. As the geographic range of the epidemic has expanded eastward beyond the Rocky Mountains, MPB has become a threat to jack pine (Pinus banksiana Lamb.), the dominant pine species of Canada's boreal forest. MPB has successfully colonized jack pine in the lodgepole pine/jack pine hybrid zone [3]. The beetle may have similar reproductive success and survival on lodgepole pine and jack pine $[4,5]$. While the suitability of jack pine as a major host for MPB and the ability of these trees to survive during outbreak of MPB are unknown, host range expansion of MPB from lodgepole pine into jack pine forests has heightened the risk of increased environmental impact of the MPB epidemic.

Successful MPB colonization of pine trees occurs when host defences are weakened or when mass attack by MPB and associated fungi overwhelm host defences $[6,7]$. One of several defence mechanisms employed by conifer trees is the production of terpenoid oleoresin, which acts as a physical and chemical barrier against insect and pathogen attack [8-10]. Oleoresin is stored in resin ducts of conifer bark, wood and needles and is primarily composed of $\mathrm{C}_{10}$ monoterpenes and $\mathrm{C}_{20}$ diterpene resin acids [11-13]. Monoterpenes are involved in the constitutive and induced defence response of lodgepole pine against adult bark beetles, brood, and beetle-associated fungi; however, the effectiveness of monoterpenes against MPB is variable and may depend on beetle population density $[7,14]$. During dispersal flight, adult MPB also exploit pine monoterpenes as cues to identify suitable host trees and as precursors for their pheromone biosynthesis [15]. Insect-associated fungi also play a role in the MPB epidemic. The MPB-associated pine pathogen Grosmannia clavigera has molecular mechanisms for transport and tolerance of certain monoterpenes [16]. In culture, $G$. clavigera can use the monoterpene (+)-limonene as a carbon source [17].

Lodgepole pine trees respond with induced accumulation of monoterpenes after MPB attack [18] or after inoculation with G. clavigera (also previously referred to as Ceratocystis clavigera or Europhium clavigerum) $[7,19,20]$. Lodgepole pine survival is positively correlated with high levels of oleoresin secretion after fungal inoculation [21], and lodgepole pine trees with high levels of monoterpenes had decreased frequency of attack at low MPB population density [7]. Previous analyses identified $(-)-\beta$-phellandrene and $(-)-\beta$-pinene as the most abundant oleoresin monoterpenes of lodgepole pine, with moderate levels of $(+)-3$-carene and $\alpha$-pinene also detected [7,22-25]. The primary monoterpenes of jack pine oleoresin were reported as $\alpha$-pinene and 3-carene, with lower amounts of $\beta$-pinene, limonene and myrcene $[26,27]$. Comparison of the volatile emissions showed that lodgepole pine emitted higher amounts of $\beta$-phellandrene and $\beta$-pinene, while jack pine emitted higher levels of $\alpha$ pinene and 3-carene [27]. Crude extracts from xylem of lodgepole pine saplings contain terpene synthase (TPS) activity for biosynthesis of (-)- $\beta$-phellandrene, $(+)$-3-carene, $(-)-\beta$-pinene and $(-)$-sabinene, consistent with the xylem monoterpene profiles [28]; however the lodgepole pine and jack pine genes involved in the biosynthesis of monoterpenes are not known.

TPSs catalyse the ionization, rearrangement, and often the cyclization of short-chain isoprenyl diphosphates to produce the core structures of thousands of different terpenes found in plants [29-31]. Conifer mono-TPSs use geranyl diphosphate (GPP) as a substrate to form, typically in a stereo-specific fashion, acyclic, monocyclic or bicyclic monoterpenes. Mono-TPSs can be single- or, more commonly, multi-product enzymes [11,32]. Genomes of conifers harbour families of closely related mono-TPSs as was evident from EST analyses and fulllength (FL)cDNA characterization of TPSs from Norway spruce (Picea abies), Sitka spruce (P. sitchensis) and white spruce (P. glauca) [32,33]. For example, analysis of ESTs from Sitka spruce and white spruce led to the identification and functional characterization of 15 mono-TPSs [32]. In contrast, for species of pine, to the best of our knowledge only three loblolly pine ( $P$. taeda) mono-TPSs have been functionally characterized, which form either $(+)$ - $\alpha$-pinene, $(-)-\alpha-$ pinene, or $(-)-\alpha$-terpineol as major products [34].

We report here the generation of large transcriptome sequence resources for jack pine and lodgepole pine obtained with Sanger, 454 and Illumina sequencing technologies. The quality of assemblies for FLcDNA discovery was evaluated by comparison with a core set of eukaryotic genes and by mining for sequences involved in terpenoid biosynthesis, specifically prenyl transferases (PTs), TPSs, and cytochrome P450s of the CYP720B subfamily. These enzymes control chain length (PT; [35]), core structures (TPSs, [11), and oxidative modifications (CYP720B; [36]) of terpenoids. This analysis led to the FLcDNA cloning and functional characterization of nine jack pine and eight lodgepole pine mono-TPSs. Monoterpene metabolite profiling of six tissue types from jack pine and lodgepole pine confirmed that we identified a set of mono-TPSs that account for the majority of monoterpenes in these tree species.

\section{Results}

Generation of jack pine and lodgepole pine transcriptome sequences and assemblies

We used the Sanger, 454 Titanium, and Illumina GA or Illumina HiSeq2000 platforms to generate transcriptome 
sequences for lodgepole pine and jack pine (Additional file 1: Table S1). For Sanger sequencing, we used normalized cDNA libraries from wound-treated stem tissues of a single lodgepole pine tree and four jack pine trees. Sequencing of the cDNA resulted in 41,134 paired-end reads for lodgepole pine and 36,334 paired-end reads for jack pine. For 454 and Illumina sequencing, libraries were made from the stem tissues of an individual 2-year old lodgepole pine and an individual 2-year old jack pine, both of which were wound- and methyl jasmonatetreated to induce defence responses [37]. 454 Titanium sequencing resulted in approximately 1.3 and 1.4 million reads for lodgepole pine and jack pine, respectively. Sequencing of the lodgepole pine cDNA library using the Illumina GAII platform yielded 58.5 million pairedend reads, whereas sequencing of jack pine cDNA using Illumina HiSeq2000 technology yielded 202.3 million paired-end reads.

Sanger sequences were CAP3 assembled [38]. The average insert sizes for the four normalized cDNA libraries varied from 929 to $1,136 \mathrm{bp}$. The lodgepole pine and jack pine assemblies each contained approximately 10,000 contigs and 4,000 singletons for 14,000 putatively unique genes (Additional file 2: Table S2). Newbler (Roche) assembly of 454 sequences gave 36,923 contigs for lodgepole pine and 33,974 contigs for jack pine, which corresponded to approximately 30,000 putatively unique genes for each species. Trinity [39] assembly of Illumina sequences gave 41,567 contigs for lodgepole pine and 55,416 contigs for jack pine, which also corresponded to approximately 30,000 putatively unique genes for each species. Assemblies of Sanger and 454 sequences, i.e. hybrid assemblies, were constructed using Newbler. These assemblies gave 33,589 and 31,327 contigs for lodgepole pine and jack pine, respectively, which represented approximately 20,000 putatively unique genes for each species (Additional file 2: Table S2).

\section{Assessment of assemblies for FLcDNA recovery using CEGMA genes}

To evaluate and compare the assemblies for FLcDNA recovery, each assembly was first assessed for the presence of highly conserved eukaryotic proteins using "Core Eukaryotic Genes Mapping Approaches" (CEGMA) trained on a set of 458 Arabidopsis thaliana core proteins [40]. In the lodgepole pine and jack pine Sanger sequence assemblies $45-46 \%$ of the CEGMA protein matches were FL and an additional $37 \%$ were present but not FL (Additional file 3: Table S3). Forty-four of 84 CEGMA proteins that were not found in the jack pine assembly were also absent in the lodgepole pine assembly. The lodgepole pine and jack pine 454 sequence assemblies had almost perfect coverage with $97-98 \%$ of the CEGMA proteins represented, of which $70-71 \%$ were
FL. Nine of the 11 proteins that were not detected in the lodgepole pine assembly were also not present in the jack pine assembly. Similarly, the lodgepole pine and jack pine Illumina sequence assemblies contained near perfect coverage (98-99\%) of CEGMA proteins, with a slightly higher percentage of FL coverage $(76.5 \%$ and $77.4 \%$, respectively). Five of the six CEGMA proteins that were absent in the lodgepole pine Illumina assembly were also absent in the jack pine assembly. The hybrid Sanger/454 assemblies for lodgepole pine and jack pine each contained $97 \%$ of the CEGMA proteins, with approximately $70 \%$ of these being FL. Most CEGMA genes identified in the Sanger sequences were also present in the 454 and Illumina sequences. With one exception, all of the CEGMA genes that were missing in the Illumina sequence assemblies were also absent in the Sanger and 454 sequence assemblies.

\section{Assessment of assemblies for FLCDNA recovery using terpenoid pathway genes}

To assess and compare the utility of the lodgepole pine and jack pine transcriptome assemblies for FLcDNA discovery of terpenoid pathway genes, each assembly was queried with known PTs, TPSs, and CYP450s from other species. These searches identified sequences for 7 unique PTs, 19 unique TPSs, and 8 unique CYP720Bs in lodgepole pine (total 34 unique genes); and 9 unique PTs, 21 unique TPSs and 8 unique CYP720Bs in jack pine (total 38 unique genes). We then assessed the coverage of these 34 and 38 genes with quality terms "full-length (FL)", "not full-length (not FL)" or "not present (NP)" in each of the different assemblies (Additional file 4: Table S4). The 454 and 454/Sanger sequence assemblies had the best FL coverage with, respectively, 14 and 13 out of 34 targets being FL for lodgepole pine, and 20 out of 38 targets being FL for jack pine. The Illumina sequence assemblies had the highest overall coverage with 27 out of 34 genes present for lodgepole pine, and 32 out of 38 genes in jack pine, but these assemblies had lower FL sequence coverage. The Sanger sequence assemblies contained less than half of the target genes for each species, with no FL coverage for TPSs and CYP720Bs for lodgepole pine and only one FL TPS and one FL CYP720B for jack pine. Based on these results we used the Sanger/454 hybrid assembly for obtaining FLcDNAs of PTs, TPSs and CYP720Bs. The Illumina sequences will be useful for the discovery of additional genes of these families, which will require additional efforts to produce FLcDNAs.

\section{Mining of the 454/Sanger hybrid assembly for PT, TPS, and CYP720 genes}

Overall, the lodgepole pine Sanger/454 hybrid assembly contained 259 CYP450-like contigs with 14 contigs representing the CYP720B subfamily. The jack pine 
assembly contained 339 CYP450-like contigs including 31 CYP720B contigs. As detailed above, analysis of the lodgepole pine and jack pine assemblies revealed, respectively, 6 and 7 unique CYP720B putative FL sequences. BLAST search outputs for PT and TPS sequences suggested that many of these genes were present in the assemblies with several closely related variants. Such closely related variants, which are typical for gene families of secondary metabolism, are extremely difficult to resolve in sequence databases. To further assess closely related variants, all sequences identified as PTs or TPSs were isolated from the larger sequence datasets and re-assembled using Phrap [41] to obtain an improved set of PT and TPS candidates. Mining of the lodgepole pine Phrap assembly identified 20 PT and 62 TPS sequences. Mining of the jack pine Phrap assembly identified 27 PT and 76 TPS candidates. Further manual inspection of the TPS candidates to remove sequences with mis-spliced introns or obvious sequence problems revealed a set of $10 \mathrm{FL}$ and 23 partial TPS sequences in lodgepole pine (33 total), and $7 \mathrm{FL}$ and 38 partial candidate TPSs in jack pine (45 total). Analysis of the PT sequences identified $7 \mathrm{FL}$ and 6 partial sequences from lodgepole pine, and $9 \mathrm{FL}$ and 2 partial sequences from jack pine.

\section{Cloning and characterization of mono-TPS FL CDNAs}

Within the set of 33 lodgepole pine TPSs and 45 jack pine TPSs we searched for the subset of mono-TPSs using BLAST searches and expert sequence assessments against previously known conifer mono-TPSs, including those described in Keeling et al. [32]. Characterization of di-TPSs was recently published [42]. We found $7 \mathrm{FL}$ and 10 partial mono-TPS candidates for lodgepole pine, and $5 \mathrm{FL}$ and 24 partial mono-TPS candidates for jack pine. FL mono-TPSs were recovered from plasmids used for Sanger sequencing or by PCR using cDNA template. Rapid amplification of cDNA ends (RACE) led to the cloning of additional FL mono-TPSs. We cloned a total of 9 lodgepole pine and 11 jack pine FL mono-TPS cDNAs for recombinant expression in E. coli and characterization of TPS enzyme functions. Eight lodgepole pine and 9 jack pine TPS proteins showed activity with GPP as a substrate, confirming their identity as mono-TPSs. Assays using neryl diphosphate as a substrate produced only trace amounts of monoterpene products, and no product formation was detected with farnesyl diphosphate (FPP) or geranylgeranyl diphosphate (GGPP).

Functional characterization of (-)- and (+)-a-pinene, (-)- $\beta$ phellandrene, and (-)-camphene synthases

Mono-TPS enzymes that produced product profiles dominated by $92 \%$ and $88 \%(+)-\alpha$-pinene were cloned from lodgepole pine [PcTPS- $(+) \alpha p i n 1]$ and jack pine

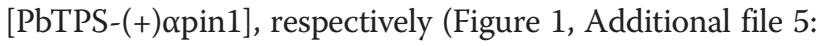

Table S5). These proteins had $98 \%$ amino acid sequence identity to each other and to the previously characterized loblolly pine $(+)-\alpha$-pinene synthase [34]. Two additional jack pine candidates (PbTPS-mono1, PbTPS-mono2) had $98 \%$ sequence identity to each other and $90 \%$ identity to the $(+)-\alpha$-pinene synthases; however, these proteins showed no activity with GPP, GGPP or FPP. One protein

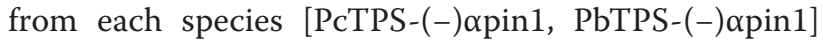
produced $77-78 \%(-)-\alpha$-pinene and 10\% (-)- $\beta$-pinene. These proteins also had $98 \%$ amino acid sequence identity to each other and to loblolly pine (-)- $\alpha$-pinene synthase [34].

Two lodgepole pine cDNAs [PcTPS-(-)ßphell1, PcTPS(-)Bphell2] and one jack pine cDNA [PbTPS-(-)ßphell1] had $95-99 \%$ protein sequence identity to each other and had $70 \%$ sequence identity to PbTPS-(+)apin1, PcTPS$(+) \alpha p i n 1$ and PtTPS- $(+) \alpha p i n 1$. These enzymes produced $82-88 \%$ (-)- $\beta$-phellandrene as the dominant product (Figure 1, Additional file 5: Table S5). A third lodgepole pine candidate [PcTPS-(-)camp/(+)apin] had 95\% identity to both the jack pine and lodgepole pine $(-)-\beta$-phellandrene synthases, and $70 \%$ identity to the $(+)-\alpha$-pinene synthases, but produced 29\% (-)-camphene and 26\% (+)- $\alpha$-pinene along with other minor products (Figure 1, Additional file 5: Table S5).

\section{Functional characterization of (-)- $\beta$-pinene, $\alpha$-terpineol, and (+)-3-carene synthases}

Two lodgepole pine mono-TPS candidates [PcTPS(-)Bpin1, PcTPS-mono1] and two jack pine candidates [PbTPS-(-)ßpin1, PbTPS-(-)ßpin2] had 96-98\% amino acid sequence identity to each other and $91-93 \%$ sequence identity to loblolly pine (-)- $\alpha$-terpineol synthase [34]. Surprisingly, none of these four proteins produced $\alpha$ terpineol but instead produced $75-81 \%(-)-\beta$-pinene and $8-13 \%(-)-\alpha-$ pinene (Figure 1, Additional file 5: Table S5). The second lodgepole pine candidate (PcTPS-mono1) did not show any activity with GPP, FPP or GGPP, either as FL or truncated protein lacking the putative plastid targeting sequence. A third jack pine protein [PbTPS- $(-) \alpha / \beta$ pin1] had $92-97 \%$ sequence identity to the (-)- $\beta$-pinene synthases but instead produced a mixture of $39 \%(-)-\alpha$-pinene and $33 \%(-)-\beta$-pinene.

One candidate from each of jack pine (PbTPS- $\alpha$ terp) and lodgepole pine (PcTPS- $\alpha$ terp) had 92\% sequence identity to each other and formed $\alpha$-terpineol as the major product. These proteins had only $62 \%$ sequence identity to the PtTPS-(-)aterp [34] and were most closely related ( $77 \%$ identity) to 1,8-cineole synthases from white spruce and a white spruce hybrid [32]. Surprisingly, analysis of the stereochemistry of the $\alpha$ terpineol product suggested that PbTPS- $\alpha$ terp produced a mixture of $44 \%(+)$ and $56 \%(-)$-enantiomers, whereas PcTPS- $\alpha$ terp produced only the (-)-enantiomer. PbTPS- 


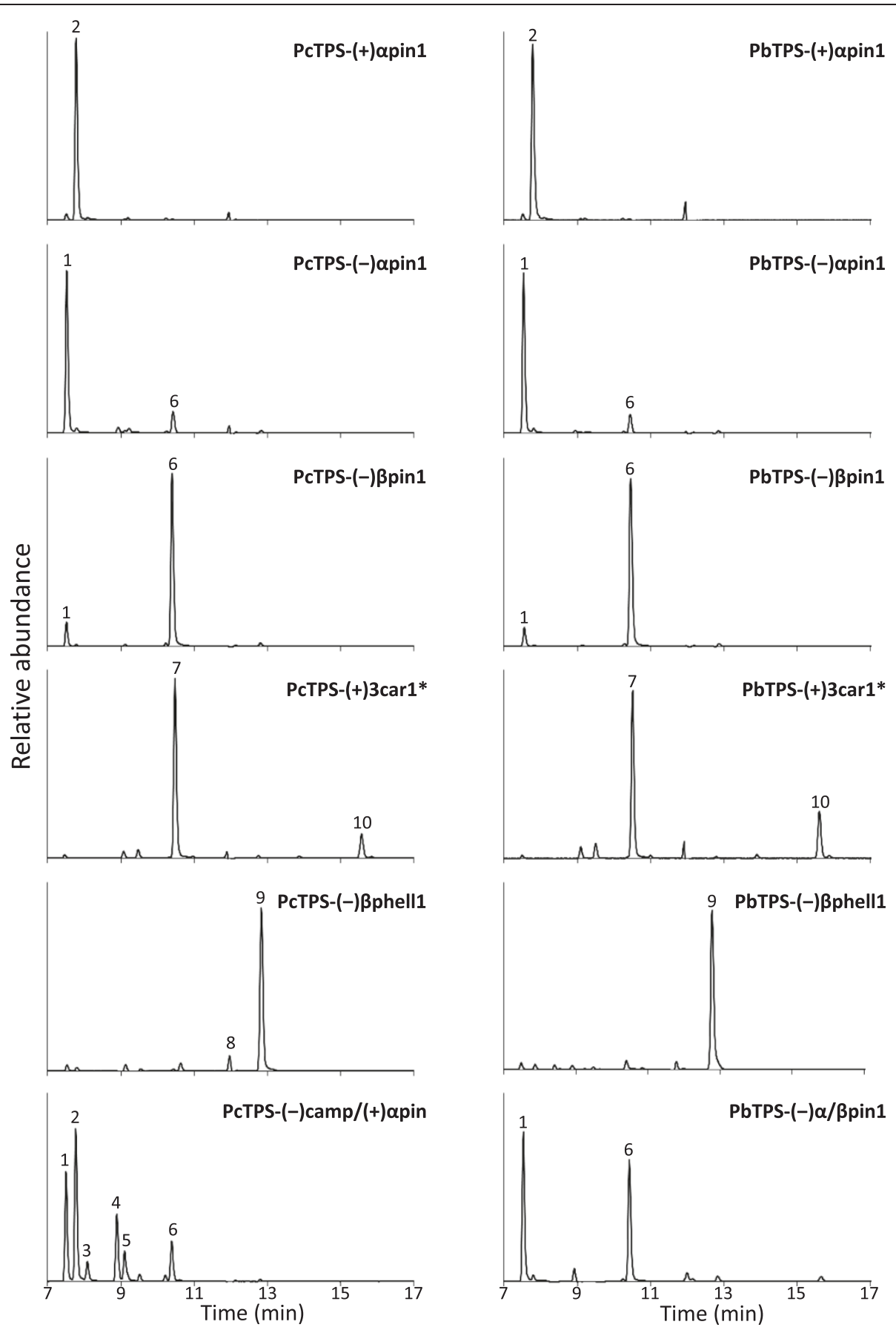

Figure 1 Representative chiral gas chromatographic separation of enzymatic products from select recombinant lodgepole pine and jack pine monoterpene synthases that produce non-oxygenated monoterpenes as their main products. Products representing greater than $5 \%$ of the total amount are labeled. 1, (-)-a-pinene; 2 , (+)-a-pinene; 3, tricyclene; 4, (-)-camphene; 5, myrcene; 6, (-)- $\beta$-pinene; 7, (+)-3carene; 8, (-)-a-phellandrene; 9, (-)- $\beta$-phellandrene; 10, terpinolene. * GC/MS traces for PcTPS- $(+) 3$ car1, PbTPS-(+)3car1 and PbTPS- $(+) 3 c a r 2$ also showed 5\%, 12\% and 7\% a-terpineol respectively, which elutes later than the scale shown, but are detailed in Additional file 5: Table S5.

aterp also produced 17\% terpin-4-ol, 10\% geraniol, 9\% terpinolene and 5\% (-)-limonene, while PcTPS- $\alpha$ terp produced 32\% 1,8-cineole, 9\% (-)-sabinene and 8\% myrcene as additional products (Figure 2, Additional file 5: Table S5).
Two jack pine candidates (PbTPS(+)3car1, PbTPS $(+)$ 3 car1) and one lodgepole pine candidate (PcTPS $(+)$ 3 car1) produced 56-68\% (+)-3-carene and approximately $10 \%$ terpinolene (Figure 1, Additional file 5: Table S5). These proteins had $88-96 \%$ protein sequence identity to 


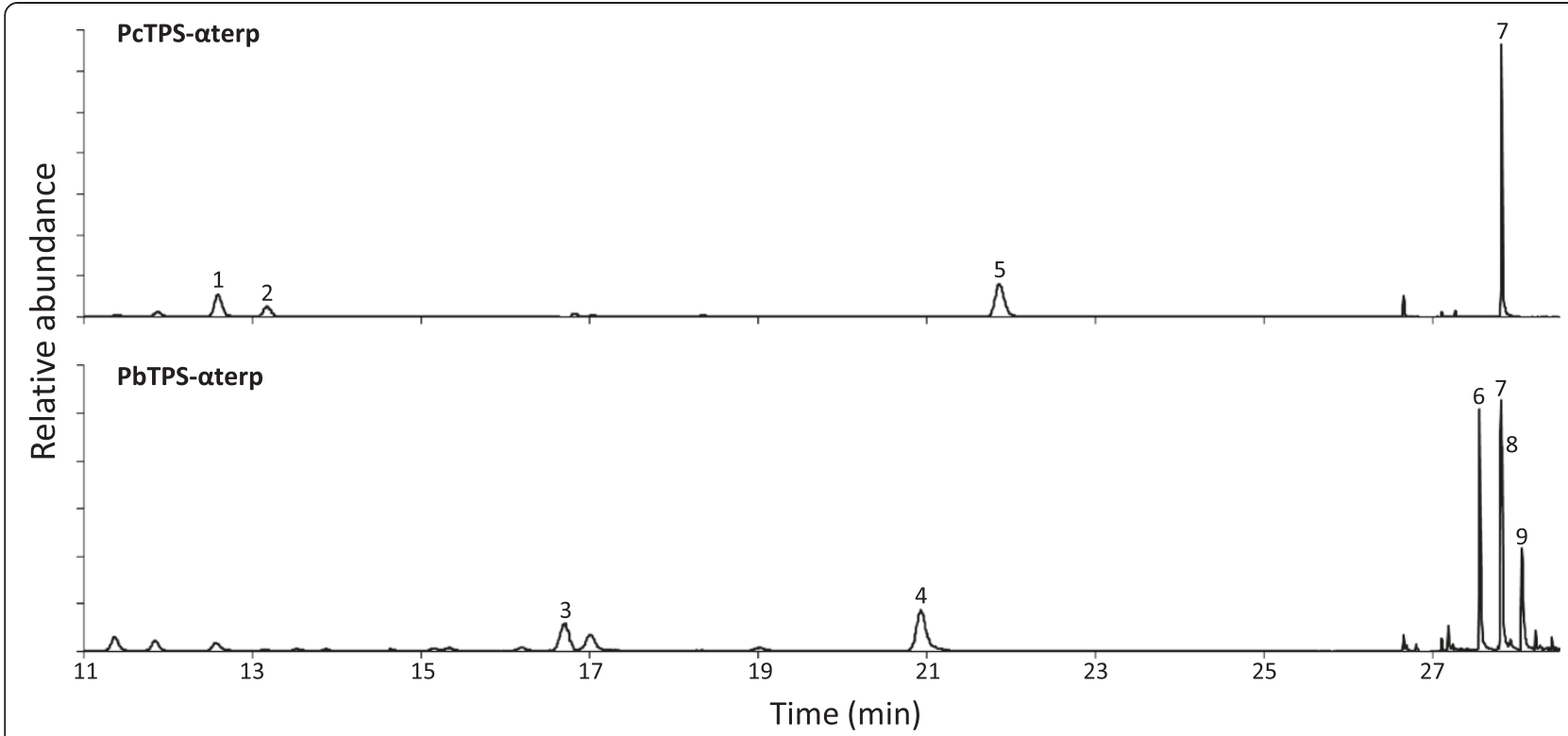

Figure 2 Representative chiral gas chromatographic separation of enzymatic products from recombinant lodgepole pine and jack pine monoterpene synthases that produce oxygenated monoterpenes as their main product. Products representing greater than 5\% of the total amount are labeled. 1, myrcene; 2, (-)-sabinene; 3, (-)-limonene; 4, terpinolene; 5 1,8-cineole; 6, terpin-4-ol; 7, (-)-a-terpineol; 8, (+)-aterpineol; 9, geraniol.

each other and were most closely related (69-79\% identity) to (+)-3-carene synthases from Norway spruce, Sitka spruce and white spruce $[32,43,44]$.

\section{Monoterpene profiles of jack pine and lodgepole pine}

To assess if products of the recombinant mono-TPS proteins were present in pine tissues, monoterpenes were extracted and analysed from the apical buds, leader stem, young needles (from the leader), first interwhorl stem, mature needles (from the first interwhorl) and roots of 3-year old jack pine and lodgepole pine saplings. In both pine species, the roots contained the lowest amount of total monoterpenes (Figure 3). Five of the six tissues of lodgepole pine contained $52-58 \%(-)-\beta$-phellandrene and $20-35 \%$ (-)- $\beta$-pinene as the two most abundant monoterpenes, with the exception that lodgepole pine roots contained $21 \%(-)-\beta$-phellandrene, 33\% $(-)-\beta$-pinene and $32 \%(+)-3$-carene. All lodgepole pine tissues contained approximately $3 \%(-)-\alpha-$ pinene and the lodgepole pine apical buds, interwhorl stem and leader stem contained 7-8\% (+)-3-carene and less than $1 \%$ of several additional monoterpenes including (+)- $\alpha$-pinene, (+)- $\beta$-pinene, myrcene, terpinolene and both isomers of limonene and camphene (Figure 3).

Leader stem and interwhorl stem tissues of jack pine contained a complex mixture of monoterpenes, containing 26-29\% (+)-3-carene, 21\% (+)- $\alpha$-pinene and $18 \%(-)-\beta$-pinene, $8-10 \% \quad(-)$ - $\alpha$-pinene, $7 \%$ (-)-limonene, 4-5\% bornyl acetate and $2 \%(-)-\beta-$ phellandrene, myrcene and terpinolene. Monoterpene profiles of jack pine needles contained 15-24\% $(-)$ - $\beta$-pinene, $14-18 \%$ bornyl acetate as well as $6-15$ $\%$ of $(-)$ - $\alpha$-pinene, $(+)$ - $\alpha$-pinene, $(+)$-3-carene, $(-)-\beta$ phellandrene, (-)-limonene. Jack pine apical buds contained 27\% (+)-3-carene, 20\% (-)- $\beta$-pinene, $6 \%$ bornyl acetate, $7 \%(+)-\alpha$-pinene as well as $11 \%$ $(-)$ - $\alpha$-pinene and (-)-limonene (Figure 3 ).

Phylogeny of the lodgepole pine and jack pine mono-TPSs A neighbour joining phylogeny placed all of the FL jack pine and lodgepole pine mono-TPSs within the TPS-d1 family ([32]; Figure 4, Additional file 6: Table S6). Many of the jack pine and lodgepole pine mono-TPSs grouped together with functionally related mono-TPSs from other conifer species. For example, the jack pine and lodgepole pine (+)-3-carene synthases grouped together with spruce (+)-3-carene synthases $[32,43,44]$ and the Pseudotsuga menziesii terpinolene synthase [45]. Similarly, the pine $(-)-\alpha$-pinene synthases (Figure 1; Additional file 6: Table S6; [34]) grouped most closely with spruce and fir enzymes that produce $(-)$ - $\alpha$-pinene and $(-)-\beta$-pinene $[32,33,46]$. Conversely, the lodgepole pine and jack pine (-)- $\beta$ pinene synthases grouped together with the loblolly pine (-)- $\alpha$-terpineol synthase [34] and were most closely related to the spruce (-)- $\beta$-phellandrene synthases [32], whereas the jack pine and lodgepole 


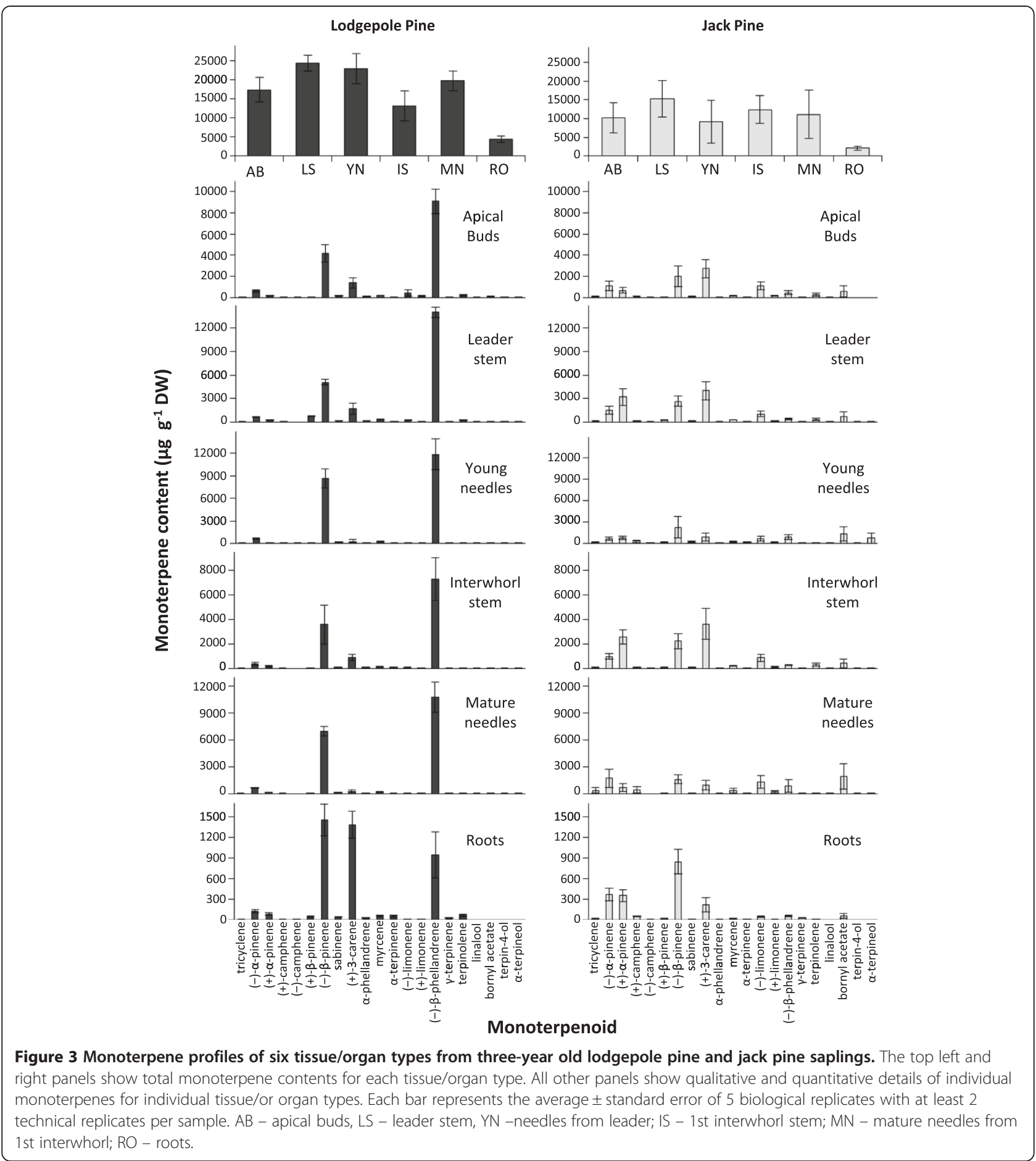

pine $\alpha$-terpineol synthases grouped together with spruce enzymes that produce (-)-linalool and 1,8cineole (Figure 2, [32,33]). The jack pine and lodgepole pine (-)- $\beta$-phellandrene synthases grouped together with pine $(+)$ - $\alpha$-pinene synthases (Figure 1; Additional file 1: Table S1; [34]) and grouped separately from other previously characterized conifer $(-)-\beta$-phellandrene synthases [32].

\section{Discussion}

Identification of FL transcripts of genes of terpenoid metabolism

We present transcriptome sequence resources generated with Sanger, 454, and Illumina technologies to enable gene discovery in jack pine and lodgepole pine. Different assemblies were generated to assess the ability to reconstruct FL transcripts. Previous work identified Newbler 


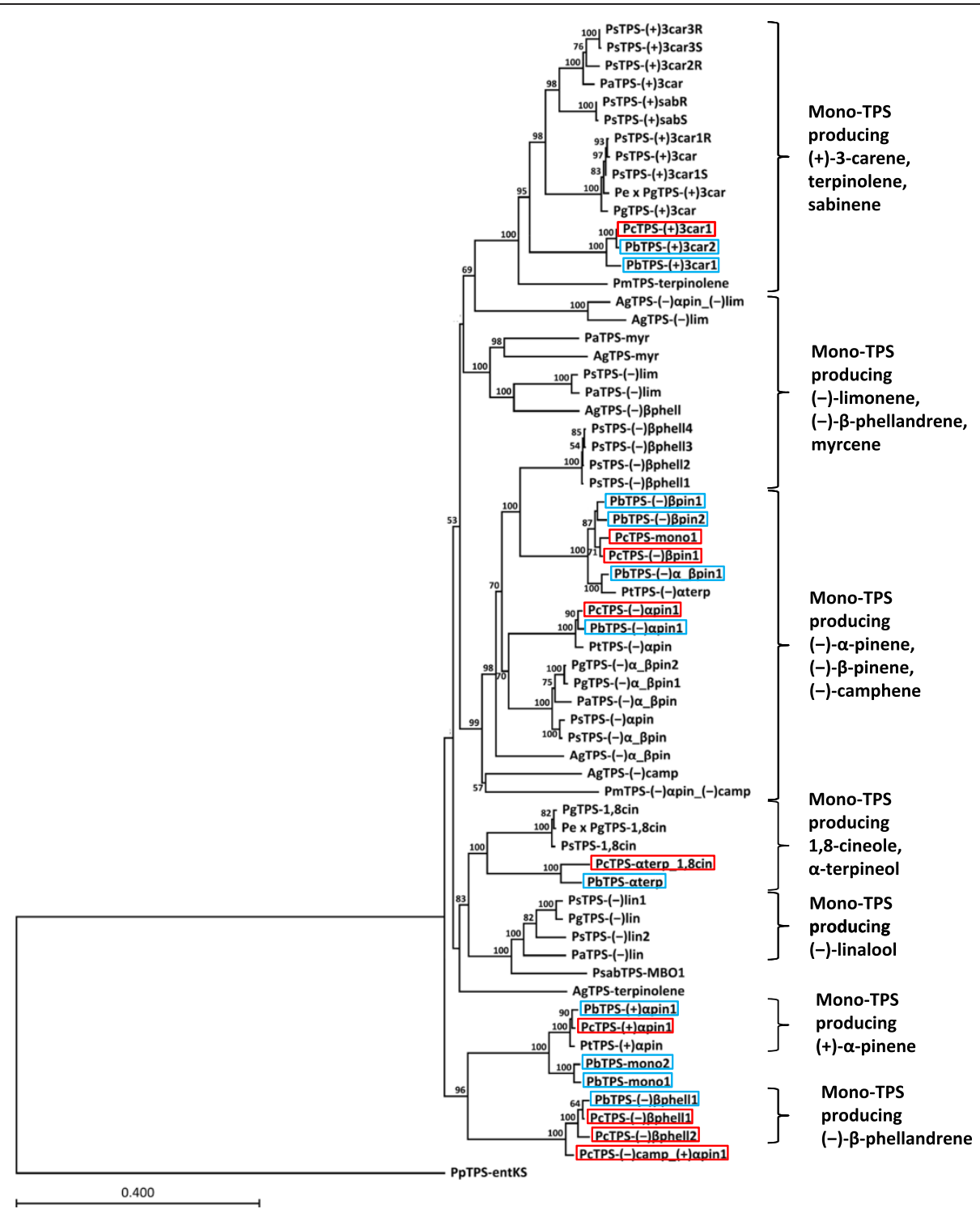

Figure 4 Phylogeny of FL mono-TPSs from lodgepole pine and jack with previously characterized conifer mono-TPSs. Bootstrap values greater than 50\% are indicated at nodes. Abbreviations and NCBI accession numbers are located in Additional file 6: Table S6. Mono-TPSs characterized in this report are outlined in red (lodgepole pine) or blue (jack pine).

as ideal for obtaining FL transcripts from 454 sequences of non-model organisms [47]. We also used the Trinity assembler to process Illumina sequences. tBLASTn searches of the assemblies using CEGMA [40] proved useful as a general assessment of FL transcript recovery. The shorter length of the Illumina sequences did not appear to be a disadvantage and appeared to be compensated by the depth of coverage, which allowed us to recover most of the CEGMA genes with FL transcripts in both pine species.

A major challenge of conifer transcriptome analysis is the proper assembly of FL sequences of members of multigene families, where closely related members have divergent functions, and which are characteristic of secondary metabolism. TPS and P450 genes such as the conifer TPS-d and CYP720B genes are examples of such multigene families $[31,32,36]$. As a strategy for discovery and resolution of members of large gene families such as the TPSs in conifers we used the re-assembly of target genes after initial large-scale de novo transcriptome assembly. We have previously used this approach as part of a transcriptome assembly and gene discovery pipeline that was validated with known conifer di-TPSs and led to the successful discovery of new di-TPS genes of previously unknown functions in balsam fir (Abies balsamea) [48], lodgepole pine, and jack pine [42]. 


\section{Mono-TPSs accounted for major components of the monoterpene metabolite profiles of lodgepole pine and jack pine}

The dominant monoterpenes across the different organ and tissue types of lodgepole pine were $(-)-\beta-$ phellandrene and (-)- $\beta$-pinene (Figure 3 ). Consistent with these profiles, two (-)- $\beta$-phellandrene synthases and one (-)- $\beta$-pinene synthase were characterized from lodgepole pine. Additional mono-TPSs were also characterized from lodgepole pine that produced $(+)-\alpha-$ pinene, (-)- $\alpha$-pinene, $(-)$-camphene, $(+)$-3-carene, and $\alpha$-terpineol. The most abundant monoterpenes in jack pine were $(+)-\alpha$-pinene, $(-)-\alpha$-pinene, $(-)-\beta$-pinene and $(+)$-3-carene. We identified the mono-TPSs responsible for the biosynthesis of these metabolites as well as the synthases that produce (-)- $\beta$-phellandrene and $\alpha$ terpineol. Bornyl acetate and (-)-limonene were also present in moderate amounts in all jack pine tissues tested. However, the synthases responsible for the production of these compounds have not been identified. In other conifers, mono-TPSs that produce (-)-limonene have been identified from grand fir [46], Norway spruce [33] and Sitka spruce [49]. Crude enzyme extracts from liverwort (Conocephalum conicum) catalyse the conversion of GPP to bornyl diphosphate [50], the likely precursor to bornyl acetate. A gene responsible for the biosynthesis of (+)-bornyl diphosphate was characterized in Salvia officinalis [51]. However, the genes involved in bornyl acetate biosynthesis have not been identified in any conifer species. The sequences of the TPSs that produce the remainder of the monoterpenes detected in lodgepole pine and jack pine, including (-)-limonene and bornyl acetate, are likely to be present within our assemblies in the form of partial transcripts. Additional approaches, such as targeted RACE, may be required to obtain the FL cDNAs for functional characterization. Among the partial or uncharacterized mono-TPS-like genes from jack pine and lodgepole pine, there may also be TPSs that use dimethylallyl diphosphate as a substrate to produce hemiterpenes, as was recently shown in Pinus sabiniana [52]. This possibility will be tested in future work. Using lodgepole pine and jack pine transcriptome resources, the discovery of a set of bifunctional and monofunctional di-TPSs was recently reported [42]. Together, these di-TPSs and the mono-TPSs described here account for the majority of oleoresin defence compounds of lodgepole pine and jack pine.

The discovery of two (+)-3-carene synthases from jack pine and one $(+)-3$-carene synthase from lodgepole pine may suggest that copy number variation in the $(+)-3-$ carene synthases account for the difference in (+)-3-carene content in these trees, similar to the copy number variation of (+)-3-carene phenotypes in Sitka spruce [44]. Previous research has identified (+)-3-carene as important in the defence of Chinese pine (Pinus tabuliformis) against the red turpentine beetle (Dendroctonus valens) and its associated fungus (Leptographium procerum) [53]. Additionally, (+)-3-carene is associated with the resistance of Sitka spruce to the white pine weevil $[44,54]$. The $(+)-3-$ carene content in all tissue types of jack pine was higher than the content of the corresponding tissue in lodgepole pine, consistent with previous comparisons of jack pine and lodgepole pine volatile emission and oleoresin content [27]. The monoterpene content in lodgepole pine, including (+)-3-carene, has strong genetic [55] and geographical [25] components, and has important consequences in MPB host colonization [14].

\section{Functional diversification of jack pine and lodgepole pine mono-TPSs}

Gene duplication followed by sub- and neo-functionalization is likely the origin of the large conifer TPS gene family of oleoresin biosynthesis [31-33,56]. The 17 mono-TPSs characterized in this study provide additional insight into the molecular underpinnings of the monoterpene diversity observed across conifer species. The jack pine and lodgepole pine mono-TPS genes are members of the TPS-d1 family containing conifer mono-TPSs [31-33]. Many of the pine monoTPSs, including the genes responsible for (+)-3-carene and (-)- $\alpha$-pinene biosynthesis, group phylogenetically with functionally similar mono-TPSs from loblolly pine, grand fir and spruce. This functional conservation across species suggests that considerable gene duplication and functionalization occurred prior to the speciation of pine, fir and spruce.

The jack pine and lodgepole pine (+)- $\alpha$-pinene synthases and $(-)-\beta$-phellandrene synthases grouped together with the previously characterized loblolly pine $(+)-\alpha$-pinene synthase [34] as a unique and apparently Pinus specific subclade within the TPS-d family (Figure 4 ). The jack pine and lodgepole pine (-)- $\beta$-phellandrene synthases grouped separately from the Sitka spruce [32] and grand fir (-)- $\beta$ phellandrene synthases [57] highlighting the multiple origins of $(-)-\beta$-phellandrene biosynthesis in conifers. Genes that produce $(+)-\alpha$-pinene as their major product have not been identified in any conifer genus other than Pinus, suggesting this function may have evolved in the pine lineage after the separation from spruces and firs.

Three proteins from jack pine and lodgepole pine shared $91-93 \%$ sequence identity with the previously characterized loblolly pine (-)- $\alpha$-terpineol synthase. Based on sequence identity, one may have predicted that the jack pine and lodgepole pine proteins would similarly produce $\alpha$-terpineol. Surprisingly, these proteins produced $75-81 \%(-)-\beta$-pinene and no $\alpha$-terpineol. Previous reports demonstrate that a few amino acid substitutions are sufficient to alter the product profiles of mono-TPSs from grand fir $[58,59]$. The high level of 
sequence identity between these functionally distinct proteins from jack pine, lodgepole pine and loblolly pine serves as an example of the functional plasticity observed in conifer mono-TPS.

\section{Conclusions}

Here, we present large transcriptome resources for lodgepole pine and jack pine generated on Sanger, 454 and Illumina sequencing platforms. Beyond using highly conserved plant and eukaryotic genes for quality assessment of assemblies, we successfully focused on FLcDNA recovery and resolution of closely related sequences characteristic of large gene families of conifer defence and secondary metabolism. Expert-curated assemblies and annotation identified a substantial number of terpenoid pathway genes in the two pine species investigated here. The closely related jack pine and lodgepole pine have unique monoterpene profiles that function as defences and semiochemicals in the interactions with MPB and MPB-associated fungi as well as other pests. The diverse and different functions of the trees' monoTPSs identified here account for many of the major and minor monoterpenes in different tissues, yet also point to enzymes of terpene biosynthesis which remain to be discovered. The genes identified provide a foundation to further investigate the role of these compounds as well their intra- and interspecific variations and dynamics in the defence of jack pine and lodgepole pine to the MPB.

\section{Methods}

Origin and treatment of pine tissues and RNA extractions For Sanger sequencing, six-year old lodgepole pine (Pinus contorta) trees were provided by the BC Ministry of Forestry and Range. Trees were maintained in pots, outside at the University of British Columbia Vancouver campus. One-year old jack pine (Pinus banksiana) from the "Prince Albert West" seedlot were obtained from Forest First, SK and maintained in a growth chamber at the University of Alberta. The leader and top three interwhorls of a single lodgepole pine tree and the top interwhorl from four jack pine trees were mechanically wounded with a razor blade $1,2,4$, and 8 days prior to harvesting the tissue. At harvest, the stem sections were cut from the tree and the bark manually separated from the xylem, and the needles removed. Bark and xylem were immediately frozen separately in liquid nitrogen and stored at $-80^{\circ} \mathrm{C}$.

For 454 and Illumina sequencing and metabolite analysis, jack pine (clone ID PSB $4101+0$ ) and lodgepole pine (clone ID PLI 144) saplings were maintained outdoors at the University of British Columbia. For RNA extraction, four two-year old saplings of each species were moved into the greenhouse and were maintained at $24^{\circ} \mathrm{C}$ and $16 \mathrm{~h}$ light per day for two weeks prior to induction of defence gene expression. The stem of each tree was wounded along the whole stem with a razor blade incision $2-3 \mathrm{~cm}$ apart, and the aerial portion of the tree was sprayed with $50 \mathrm{ml}$ of $0.1 \%$ methyl jasmonate. One quarter of the stem (combined bark and xylem) of each tree was harvested $2 \mathrm{~h}, 6 \mathrm{~h}, 24 \mathrm{~h}$ and $48 \mathrm{~h}$ following treatment and the four time points from each individual were pooled prior to RNA extraction. For metabolite profiling, five three-year old saplings of each species were moved into the greenhouse for two weeks prior to harvest. Tissue samples were harvested from each tree, and flash frozen and stored at $-80^{\circ} \mathrm{C}$ until processing with the exception that combined bark and xylem tissue was cut into $1 \mathrm{~cm}$ sections prior to freezing.

\section{RNA isolation}

For Sanger sequencing, total RNA from the separated bark and xylem tissues was extracted from each of the four stem sections of the single lodgepole pine tree as described previously [60]. For jack pine, the total RNA was extracted from each individual bark and xylem tissue sample according to Pavy et al. [61] and pooled. For RACE, full-length cDNA cloning and template for 454 and Illumina sequencing, RNA from single jack pine and lodgepole pine trees was extracted and converted to cDNA as described previously [44].

\section{cDNA library construction and transcriptome sequencing}

For Sanger cDNA library construction, mRNA was purified from total RNA using the Oligotex mRNA Kit (Qiagen; www.qiagen.com) and quantified by RiboGreen (Invitrogen; www.invitrogen.com). cDNA libraries were prepared using the Creator SMART cDNA Library Construction Kit (Clontech; www.clontech.com) and the Trimmer-Direct cDNA Normalization Kit (Evrogen; www. evrogen.com). First strand cDNA was prepared from 225$1,500 \mathrm{ng}$ of total RNA in jack pine or 106-1,300 $\mu \mathrm{g}$ of poly(A) ${ }^{+}$RNA in lodgepole pine, SuperScript III reverse transcriptase (Invitrogen), CDS-3 M primer (Evrogen), and the SMART IV Oligonucleotide (Clontech). Second strand CDNA was prepared by LD-PCR with Phusion Hot Start DNA Polymerase (Finnzymes, www.finnzymes.fi). cDNA was normalized with duplex-specific nuclease and amplified following the Trimmer-Direct protocol. The cDNA was then digested with SfiI, size fractionated by gel filtration, and cDNA larger than approx. 500 bp was ligated into pDNR-LIB (Clontech). The ligations were then transformed into ElectroMAX DH10B T1 Phage-Resistant electro-competent cells (Invitrogen), titred and submitted to the Michael Smith Genome Sciences Centre for arraying and sequencing. Sanger sequencing (paired end reads) was completed using M13 forward and reverse primers. For lodgepole pine, 10,000 cDNA clones each were sequenced from the bark and xylem cDNA libraries. 
For jack pine, 15,550 and 6,528 cDNA clones were sequenced from the bark and xylem libraries, respectively.

For 454 and Illumina sequencing, cDNA libraries were prepared and sequenced at the McGill University and Génome Québec Innovation Centre, in Montreal, QC. For Roche-GS-FLX - Titanium (454) sequencing, 200 ng of mRNA was purified using the Dynabeads mRNA purification kit (Invitrogen) and was fragmented using a $\mathrm{ZnCl}_{2}$ buffer. cDNA libraries were prepared using the GS FLX Titanium Series cDNA Rapid Library preparation kit (Roche; www.roche.com) and were subjected to two halfplates (single end reads) of sequencing. For Illumina sequencing, the same lodgepole pine total RNA and a new sample of total RNA from the same jack pine individual were subjected to mRNA purification and cDNA library construction using the mRNA Seq Sample Preparation Kit (Illumina; www.illumina.com). The lodgepole pine library was subjected to 1 lane of sequencing (108 bp paired-end reads) using the Illumina Genome Analyzer iiX (Illumina GAII) platform, while the jack pine library was subjected to 1 lane of sequencing (100 bp paired-end reads) using the Illumina HiSeq 2000 platform.

\section{Filtering and assembly of jack pine and lodgepole pine transcriptome sequences}

After removal of poor quality and chimeric reads, raw Sanger sequences were screened for contaminants against Escherichia coli K12, fungi, various bacterial and archaea genomes, and all Insecta ESTs. These sequences were then trimmed using Seqclean to remove any remaining adapter sequence. 454 and Illumina sequences were inspected visually using FastQC. A custom Perl script was developed to trim the adapter remnants in both cases with the fastq file for 454 and Illumina obtained from the sequencing centre. The Sanger sequences were assembled with CAP3 [38]. Newbler (version 2.6; Roche) was used in both 454 only and 454/Sanger hybrid assembly. Trinity (version 20110519; [39]) was used in the de novo assembly of Illumina $\mathrm{GA} / \mathrm{HiSeq}$ sequences.

\section{Identification of tentatively unique genes, CEGMA FL} proteins and comparison to FL terpenoid pathway targets Arabidopsis CEGMA peptide sequences were used to query the 6-frame translated transcriptomic assemblies using TBLASTN with an e-value cut-off of $1 \times 10^{-20}$. Similarly, MEGABLAST was used to query the assemblies for FL terpenoid biosynthetic pathway genes with a cut-off set at $99 \%$ identity. A custom Perl script was developed to assess the contiguity of the predicted transcripts. Only the top hit in the BLAST alignment, with at least $90 \%$ coverage of the query peptide was considered to be FL for CEGMA genes. Terpenoid biosynthetic pathway genes that were identified as FL in at least one assembly, or that had been obtained as FL by RACE, were BLAST searched against each assembly to compare the utility of these assemblies for defence gene discovery. A final set of 7 PT, 19 TPS and 8 CYP720B genes from lodgepole pine and 9 PT, 21 TPS and 8 CYP720B from jack pine were considered FL and used for this analysis. A more stringent $95 \%$ coverage was used to be considered FL for terpenoid biosynthetic genes.

\section{Identification of candidate TPSs for CDNA cloning}

The lodgepole pine and jack pine 454 Newbler assemblies were BLAST searched with a set of 107 previously characterized mono-, sesqui- and di-TPSs, 15 previously characterized PTs and 468 previously characterized P450s. The reads contained in each of the contigs identified in the Newbler assembly that had an e-value of less than $1 \times 10^{-5}$ to terpenoid biosynthetic pathway genes were then re-assembled using Phrap [62] to obtain a finalized list of candidate genes.

\section{Cloning and characterization of monoTPSs}

FL clones were retrieved from the cDNA library used for Sanger sequencing and were cloned from pDNR-LIB into the pET28b(+) vector (EMD Chemicals, www.emdchemicals.ca) for expression. For additional clones, if RACE was required, $1 \mu \mathrm{g}$ of total RNA was processed using the SMARTer RACE cDNA amplification kit (Clontech) and this cDNA was used as a template with gene specific primers (Additional file 7: Table S7) and the universal primer mix as per the manufacturer's protocol. For cloning of FL targets from the same jack pine and lodgepole pine individuals that had been subjected to high throughput sequencing, $50 \mathrm{ng}$ of jack pine RNA and $90 \mathrm{ng}$ of lodgepole pine RNA were converted to cDNA using the Superscript III FirstStrand Synthesis System (Invitrogen) and used as a template with gene specific primers (Additional file 7: Table S7). cDNA clones were either cloned directly into the $\mathrm{pET} 28 \mathrm{~b}(+)$ vector using the In-Fusion PCR cloning system (Clontech) or were subcloned into pJET1.2 (Fermentas; www.fermentas.com) prior to subcloning to pET28b $(+)$ using In-Fusion cloning. Sequencing confirmed that the FL sequences were in frame with an $\mathrm{N}$ terminal $6 \times$ His tag in pET28b(+). Recombinant proteins were expressed, Ni-affinity purified on His SpinTrap columns (GE Healthcare), and assayed in single vials as described previously $[44,56,63]$. Bacterial pellet extracts containing recombinant protein were assayed with GPP $(20 \mu \mathrm{M}), E$,E- FPP $(70 \mu \mathrm{M})$ and GGPP $(40 \mu \mathrm{M})$ in the appropriate buffers [32] and the products were subjected to analysis by GC/MS. Candidate clones that showed activity with GPP were extracted, purified, and assayed in triplicate using GPP and its isomer NPP as substrates. 


\section{Monoterpene extraction from jack pine and lodgepole pine}

Approximately $0.1 \mathrm{~g}$ of each of six different tissue or organ types harvested from 3-year old jack pine and lodgepole pine saplings were extracted in $1.5 \mathrm{~mL}$ of tert-butyl methyl ether (Sigma) containing $1.2 \mathrm{mM}$ isobutylbenzene as an internal standard. Following shaking overnight at room temperature, $1 \mathrm{ml}$ of extract was transferred to a fresh vial and processed as described previously [54]. Extractions were repeated with five biological replicates and three technical replicates per tissue type. The six tissue types were: flushing apical buds, combined bark and xylem from the leader, young needles (from leader), combined bark and xylem from the first interwhorl, mature needles from the first interwhorl, and roots.

\section{GC/MS analysis of monoterpenes}

Gas chromatography mass spectrometry (GC/MS) analysis was performed on an Agilent 6890A Series GC system coupled to an Agilent 5975 Inert XL mass spectrometer $(70 \mathrm{eV})$, with an Agilent 7683 autosampler (Agilent Technologies, www.agilent.com) as described in the supplemental material of a previous publication [44]. All analyses were performed using pulsed splitless injection mode with an injector temperature of $250^{\circ} \mathrm{C}$. Data was analysed using Enhanced MSD Chemstation E.01.00 (Agilent Technologies). Data was collected using both full scan $(m / z 40-400)$ and monoterpene-specific selective ion-monitoring $(\mathrm{m} / \mathrm{z} 69,93,121,134,136)$ mode. Monoterpenes were identified by comparison of mass spectra and retention times of authentic standards, and by comparison to mass spectral libraries (Wiley7Nist05). Response factors were calculated based on a known concentration of isobutylbenzene, and these values were used to quantify the monoterpene compounds.

For enzyme assays, monoterpenes were analyzed on a DB-Wax capillary column (J\&W 122-7032; $250 \mu \mathrm{m}$ internal diameter, $30 \mathrm{~m}$ length, $0.25 \mu \mathrm{m}$ film thickness, initial flow $1.0 \mathrm{ml} \mathrm{He} \mathrm{min}^{-1}$ ) starting at a temperature of $40^{\circ} \mathrm{C}$ which was held for $4 \mathrm{~min}$. The temperature was increased by $3^{\circ} \mathrm{C}$ per $\min ^{-1}$ to $85^{\circ} \mathrm{C}$, at which point the temperature was increased by $30^{\circ} \mathrm{min}^{-1}$ to a final temperature of $250^{\circ} \mathrm{C}$, which was held for $3 \mathrm{~min}$ (total run time $27 \mathrm{~min}$ ).

Monoterpenes extracted from pine tissue samples were separated on a SGE SolGel-Wax capillary column (SGE Analytical Science 054796, $250 \mu \mathrm{m}$ internal diameter, $30 \mathrm{~m}$ length, $0.25 \mu \mathrm{m}$ film thickness, initial flow $1.1 \mathrm{ml} \mathrm{He} \mathrm{min}^{-1}$ ). An initial temperature of $40^{\circ} \mathrm{C}$ was held for $4 \mathrm{~min}$, at which point the temperature was increased at a rate of $3^{\circ} \mathrm{C} \mathrm{min}^{-1}$ to $80^{\circ} \mathrm{C}$ and then by $40^{\circ} \mathrm{C} \mathrm{min}{ }^{-1}$ to a final temperature of $275^{\circ} \mathrm{C}$, which was held for $5 \mathrm{~min}$ (total run time $27.21 \mathrm{~min}$ ).

For stereochemical analysis of enzyme assay products and tissue extracts, monoterpenes were subjected to chiral separation on a Cylcodex B capillary column (J\&W 112-2532; $250 \mu \mathrm{m}$ internal diameter, $30 \mathrm{~m}$ length, $0.25 \mu \mathrm{m}$ film thickness, initial flow $0.8 \mathrm{ml} \mathrm{He} \mathrm{min}^{-1}$ ) starting at an initial temperature of $60^{\circ} \mathrm{C}$, which was held for one minute. The temperature was increased at a rate of $1^{\circ} \mathrm{C} \mathrm{min}^{-1}$ to $84^{\circ} \mathrm{C}$, and then increased at a rate of $50^{\circ} \mathrm{C} \min ^{-1}$ to a final temperature of $240^{\circ} \mathrm{C}$, which was held for 5 min (total run time of $33.12 \mathrm{~min}$ ).

\section{Phylogenetic analysis}

CLC Main Workbench, Version 6.2 (CLCbio; www. clcbio.com) was used for all sequence analyses including alignments and phylogenetic analyses. Phylogenetic analysis and calculation of bootstrap values (100 replicates) was executed using the neighbour-joining algorithm with the manufacturer's settings following alignment with the CLC bio MUSCLE plug-in.

\section{Additional files}

Additional file 1: Table S1. Development of transcriptome sequence resources for lodgepole pine and jack pine.

Additional file 2: Table S2. Assembly of transcriptome sequences for lodgepole pine and jack pine.

Additional file 3: Table S3. Assessment of different sequencing platforms and assembly qualities using Core Eukaryotic Genes Mapping Approaches (CEGMA).

Additional file 4: Table S4. Assessment of assembly quality of (A) lodgepole pine and (B) jack pine transcriptome data for presence of full length (FL) terpenoid pathway genes.

Additional file 5: Table S5. Functional characterization of monoterpene synthases from A) lodgepole pine and B) jack pine.

Additional file 6: Table S6. NCBI Accession numbers of the amino acid sequences used for phylogenetic analysis of functionally characterized conifer monoterpene synthases.

Additional file 7: Table S7. Gene specific primers.

\section{Abbreviations}

CEGMA: Core Eukaryotic Genes Mapping Approach; di-TPS: Diterpene synthase; FL: Full-length; FPP: Farnesyl diphosphate; GC/MS: Gas chromatography mass spectrometry; GGPP: Geranylgeranyl diphosphate; GPP: Geranyl diphosphate; Mono-TPS: Monoterpene synthase; MPB: Mountain pine beetle; NPP: Neryl diphosphate; P450: Cytochrome P450; PT: Prenyl transferase; TPS: Terpene synthase.

\section{Competing interests}

The authors declare that they have no competing interests.

\section{Authors' contributions}

DEH, MMSY, SJ, ALQ, HKD, ML, HH, CIK performed experiments and data analysis. AA-V, JEKC provided new materials. NYL, TRD, SKC, SJMJ provided bioinformatics support. CB, JB conceived the study. DEH, MY, JB analysed results and wrote the paper. All authors read and approved the final manuscript.

\section{Acknowledgements}

We thank Karen Reid for excellent laboratory and project management, Niels B. Jensen for assistance with data mining, the BC Cancer Agency Michael Smith Genome Sciences Centre (Vancouver) and the McGill University and Génome Québec Innovation Centre (Montreal) for transcriptome sequencing. This work was supported with funds from the Natural Sciences and Engineering Research Council of Canada (NSERC Strategic grant to JB and 
CB), and from Genome Canada, Genome British Columbia, and Genome Alberta (The Tria Project, www.thetriaproject.ca; to JB, CB, CIK, JEKC, SJMJ). JB is a UBC Distinguished University Scholar. This research was supported by the use of computing resources provided by WestGrid and Compute/Calcul Canada.

\section{Database submissions}

Sequence data from this article have been deposited in NCBI with the following accession numbers. Sanger ESTs: NCBI dbEST GT229582-GT270713 (lodgepole pine) and GW738148-GW774480 (Jack pine); 454 and Illumina ESTs: NCBI SRA BioProject SRP009894; FL mono-TPS: NCBI GenBank accession numbers: JQ240290-JQ240309. The Tria Project is represented by NCBI umbrella BioProject PRJNA169907.

\section{Author details}

${ }^{1}$ Michael Smith Laboratories, University of British Columbia, 2185 East Mall, Vancouver, British Columbia V6T 1Z4, Canada. ${ }^{2}$ Department of Biological Sciences, University of Alberta, Edmonton, Alberta T6G 2E9, Canada. ${ }^{3}$ British Columbia Cancer Agency Genome Sciences Centre, Vancouver, British Columbia V5Z 4E6, Canada. ${ }^{4}$ Department of Wood Sciences, University of British Columbia, 2424 Main Mall, Vancouver, British Columbia V6T 1Z4, Canada.

Received: 15 March 2013 Accepted: 2 May 2013

Published: 16 May 2013

\section{References}

1. Kurz WA, Stinson G, Rampley GJ, Dymond CC, Neilson ET: Risk of natural disturbances makes future contribution of Canada's forests to the global carbon cycle highly uncertain. Proc Natl Acad Sci USA 2008, 105:1551-1555.

2. Safranyik L, Carroll AL, Régnière J, Langor DW, Riel WG, Shore TL, Peter $B$, Cooke BJ, Nealis VG, Taylor SW: Potential for range expansion of mountain pine beetle into the boreal forest of North America. Can Entomol 2010, 142:415-442.

3. Cullingham $\mathrm{Cl}$, Cooke JEK, Dang S, Davis CS, Cooke BJ, Coltman DW: Mountain pine beetle host-range expansion threatens the boreal forest. Mol Ecol 2011, 20:2157-2171.

4. Safranyik $L$, Linton D: Survival and development of mountain pine beetle broods in jack pine bolts from Ontario. Canadian Forest Service Research Notes 1982, 2:17-18

5. Cerezke HF: Egg gallery, brood production and adult characteristics of mountain pine beetle, Dendroctonus ponderosae Hopkins (Coleoptera: Scolytidae) in three pine hosts. Can Entomol 1995, 127:955-965.

6. Raffa KF, Berryman AA: The role of host plant resistance in the colonization behavior and ecology of bark beetles (Coleoptera: Scolytidae). Ecol Monogr 1983, 53:27-49.

7. Boone CK, Aukema BH, Bohlmann J, Carroll AL, Raffa KF: Efficacy of tree defense physiology varies with bark beetle population density: a basis for positive feedback in eruptive species. Can J For Res 2011, 41:1174-1188.

8. Phillips MA, Croteau RB: Resin-based defenses in conifers. Trends Plant SCi 1999, 4:184-190.

9. Franceschi VR, Krokene P, Christiansen E, Krekling T: Anatomical and chemical defenses of conifer bark against bark beetles and other pests. New Phytol 2005, 167:353-376.

10. Bohlmann J: Pine terpenoid defences in the mountain pine beetle epidemic and in other conifer pest interactions: Specialized enemies are eating holes into a diverse, dynamic and durable defence system. Tree Physiol 2012, 32:943-945.

11. Keeling Cl, Bohlmann J: Genes, enzymes and chemicals of terpenoid diversity in the constitutive and induced defence of conifers against insects and pathogens. New Phytol 2006, 170:657-675.

12. Keeling $\mathrm{Cl}$, Bohlmann J: Diterpene resin acids in conifers. Phytochemistry 2006, 67:2415-2423

13. Zulak KG, Bohlmann J: Terpenoid biosynthesis and specialized vascular cells of conifer defense. J Integr Plant Biol 2010, 52:86-97.

14. Clark EL, Huber DPW, Carroll AL: The legacy of attack: implications of very high phloem resin monoterpene levels in mass attacked lodgepole pines following successful mountain pine beetle, Dendroctonus ponderosae Hopkins, colonization. Environ Entomol 2012, 41:392-398.

15. Seybold SJ, Huber DPW, Lee JC, Graves AD, Bohlmann J: Pine monoterpenes and pine bark beetles: a marriage of convenience for defense and chemical communication. Phytochem Rev 2006, 5:143-178.
16. Wang Y, Lim L, DiGuistini S, Robertson G, Bohlmann J, Breuil C: A specialized $A B C$ efflux transporter $G c A B C-G 1$ confers monoterpene resistance to Grosmannia clavigera, a bark beetle-associated fungal pathogen of pine trees. New Phytol 2013, 197:886-898.

17. Diguistini S, Wang Y, Liao N, Taylor G, Tanguay P, Feau N, Henrissat B, Chan S, Hesse-Orce U, Massoumi Alamouti S, Tsui CKM, Docking R, Levasseur A, Robertson G, Birol I, Holt R, Marra M, Hirst M, Hamelin R, Jones S, Bohlmann J, Breuil C: Genome and transcriptome analyses of the mountain pine beetlefungal symbiont Grosmannia clavigera, a lodgepole pine pathogen. Proc Natl Acad Sci USA 2011, 108:2504-2509.

18. Shrimpton DM: Extractives associated with wound response of lodgepole pine attacked by the mountain pine beetle and associated microorganisms. Can J Bot 1973, 51:527-534.

19. Croteau R, Gurkewitz S, Johnson MA, Fisk HJ: Biochemistry of oleoresinosis. Plant Physiol 1987, 85:1123-1128.

20. Raffa KF, Berryman AA: Physiological aspects of lodgepole pine wound responses to a fungal symbiont of the mountain pine beetle, Dendroctonus ponderosae (Coleoptera: Scolytidae). Can Ent 1983, 115:723-734.

21. Raffa KF, Berryman AA: Physiological differences between lodgepole pines resistant and susceptible to the mountain pine beetle and associated microorganisms. Environ Entomol 1982, 11:486-492.

22. Forrest Gl: A rangewide comparison of outlying and central lodgepole pine populations based on oleoresin monoterpene analysis. Biochemical Syst Ecol 1987, 15:19-30.

23. Lewinsohn E, Savage TJ, Gijzen M, Croteau R: Simultaneous analysis of monoterpenes and diterpenoids of conifer oleoresin. Phytochem Analysis 1993, 4:220-225.

24. Pureswaran DS, Gries $\mathrm{R}$, Borden $\mathrm{JH}$ : Quantitative variation in monoterpenes in four species of conifers. Biochem Syst Ecol 2004, 32:1109-1136.

25. Clark EL, Carroll AL, Huber DPW: Differences in the constitutive terpene profile of lodgepole pine across a geographical range in British Columbia, and correlation with historical attack by mountain pine beetle. Can Entomol 2010, 142:557-573.

26. Aukema BH, Powell JS, Clayton MK, Raffa KF: Variation in complex semiochemical signals arising from insects and host plants. Environ Entomol 2010, 39:874-882.

27. Lusebrink I, Evenden ML, Blanchet FG, Cooke JEK, Erbilgen N: Effect of water stress and fungal inoculation on monoterpene emission from an historical and a new pine host of the mountain pine beetle. J Chem Ecol 2011, 37:1013-1026.

28. Savage TJ, Ichii H, Hume SD, Little DB, Croteau RB: Monoterpene synthases from gymnosperms and angiosperms: stereospecificity and inactivation by cysteinyl- and arginyl-directed modifying reagents. Arch Biochem Biophys 1995, 320:257-265

29. Bohlmann J, Meyer-Gauen G, Croteau R: Plant terpenoid synthases: Molecular biology and phylogenetic analysis. Proc Natl Acad Sci USA 1998, 95:4126-4133

30. Christianson DW: Structural biology and chemistry of terpenoids cyclases. Chem Rev 2006, 106:3412-3442.

31. Chen F, Tholl D, Bohlmann J, Pichersky E: The family of terpene synthases in plants: a mid-size family of genes for specialized metabolism that is highly diversified throughout the kingdom. Plant J 2011, 66:212-229.

32. Keeling Cl, Weisshaar S, Ralph SG, Jancsik S, Hamberger B, Dullat HK, Bohlmann J: Transcriptome mining, functional characterization, and phylogeny of a large terpene synthase gene family in spruce (Picea spp.). BMC Plant Biol 2011, 11:43.

33. Martin DM, Fäldt J, Bohlmann J: Functional characterization of nine Norway spruce TPS genes and evolution of gymnosperm terpene synthases of the TPS- $d$ subfamily. Plant Physiol 2004, 135:1908-1927.

34. Phillips MA, Wildung MR, Williams DC, Hyatt DC, Croteau R: cDNA isolation, functional expression, and characterization of (+)-apinene synthase and (-)-a-pinene synthase from loblolly pine (Pinus taeda): Stereocontrol in pinene biosynthesis. Arch Biochem Biophys 2003, 411:267-276.

35. Schmidt A, Waechtler B, Temp U, Krekling T, Seguin A, Gershenzon J: A bifunctional geranyl and geranylgeranyl diphosphate synthase is involved in terpene oleoresin formation in Picea abies. Plant Physiol 2010, 152:639-655.

36. Hamberger B, Ohnishi T, Hamberger B, Séguin A, Bohlmann J: Evolution of diterpene metabolism: Sitka spruce CYP720B4 catalyzes multiple oxidations 
in resin acid biosynthesis of conifer defense against insects. Plant Physiol 2011, 157:1677-1695.

37. Zulak KG, Lippert DN, Kuzyk M, Domanski D, Chou T, Borchers CH, Bohlmann J: Targeted proteomics using selected reaction monitoring (SRM) reveals the induction of specific terpene synthases in a multi-level study of methyl jasmonate treated Norway spruce (Picea abies). Plant J 2009, 60:1015-1030.

38. Huang X, Madan A: CAP3: A DNA sequence assembly program. Genome Res 1999, 9:868-877.

39. Grabherr MG, Haas BJ, Yassour M, Levin JZ, Thompson DA, Amit I, Adiconis X, Fan L, Raychowdhury R, Zeng Q, Chen Z, Mauceli E, Hacohen N, Gnirke A, Rhind N, di Palma F, Birren BW, Nusbaum C, Lindblad-Toh K, Friedman N, Regev A: Full-length transcriptome assembly from RNA-Seq data without a reference genome. Nat Biotechnol 2011, 29:644-654.

40. Parra G, Bradnam K, Korf I: CEGMA: a pipeline to accurately annotate core genes in eukaryotic genomes. Bioinformatics 2007, 23:1061-1067.

41. Ewing B, Green P: Base-calling of automated sequencer traces using phred. II. Error probabilities. Genome Res 1998, 8:186-194.

42. Hall DE, Zerbe $P$, Jancsik S, Lara Quesada A, Dullat H, Madilao LL, Yuen M, Bohlmann J: Evolution of conifer diterpene synthases: Diterpene resin acid biosynthesis in lodgepole pine and jack pine involves monofunctional and bifunctional diterpene synthases. Plant Physiol 2013, 161:600-616.

43. Fäldt J, Martin D, Miller B, Rawat S, Bohlmann J: Traumatic resin defense in Norway spruce (Picea abies): Methyl jasmonate-induced terpene synthase gene expression, and CDNA cloning and functional characterization of (+)-3-carene synthase. Plant Mol Biol 2003, 51:119-133.

44. Hall DE, Robert JA, Keeling Cl, Domanski D, Lara Quesada A, Jancsik S, Kuzyk MA, Hamberger B, Borchers CH, Bohlmann J: An integrated genomic, proteomic and biochemical analysis of (+)-3-carene biosynthesis in Sitka spruce (Picea sitchensis) genotypes that are resistant or susceptible to white pine weevil. Plant J 2011, 65:936-948.

45. Huber DPW, Philippe RN, Godard KA, Sturrock RN, Bohlmann J: Characterization of four terpene synthase cDNAs from methyl jasmonate-induced Douglas-fir, Pseudotsuga menziesii. Phytochemistry 2005, 66:1427-1439.

46. Bohlmann J, Steele CL, Croteau R: Monoterpene synthases from Grand Fir (Abies grandis). J Biol Chem 1997, 272:21784-21792.

47. Kumar S, Blaxter ML: Comparing de novo assemblers for 454 transcriptome data. BMC Genomics 2010, 11:571.

48. Zerbe P, Chiang A, Yuen M, Hamberger B, Hamberger B, Bohlmann J: Bifunctional cis-abienol synthase from Abies balsamea discovered by transcriptome sequencing and its implications for diterpenoid fragrance production. J Biol Chem 2012, 287:12121-12131.

49. Byun-McKay A, Godard KA, Toudefallah M, Martin DM, Alfaro R, King J, Bohlmann J, Plant AL: Wound-induced terpene synthase gene expression in Sitka spruce that exhibit resistance or susceptibility to attack by the white pine weevil. Plant Physiol 2006, 140:1009-1021.

50. Adam KP, Croteau R: Monoterpene biosynthesis in the liverwort (Conocephalum conicum) demonstration of sabinene synthase and bornyl diphosphate synthase. Phytochemistry 1998, 49:475-480.

51. Wise ML, Savage TJ, Katahira E, Croteau R: Monoterpene synthases from common sage (Salvia officinalis). J Biol Chem 1998, 273:14891-14899.

52. Gray DW, Breneman SR, Topper LA, Sharkey TD: Biochemical characterization and homology modeling of methylbutenol synthase and implications for understanding hemiterpene synthase evolution in plants. J Biol Chem 2011, 286:20582-20590.

53. Lu M, Wingfield MJ, Gillette NE, Mori SR, Sun JH: Complex interactions among host pines and fungi vectored by an invasive bark beetle. New Phytol 2010, 187:859-866.

54. Robert JA, Madilao LL, White R, Yanchuk A, King J, Bohlmann J: Terpenoid metabolite profiling in Sitka spruce identifies association of dehydroabietic acid, (+)-3-carene, and terpinolene with resistance against white pine weevil. Botany 2010, 2010(88):810-820.

55. Ott DS, Yanchuk AD, Huber DP, Wallin KF: Genetic variation of lodgepole pine, Pinus contorta var. latifolia, chemical and physical defenses that affect mountain pine beetle, Dendroctonus ponderosae, attack and tree mortality. J Chem Ecol 2010, 37:1002-1012.

56. Keeling Cl, Weisshaar S, Lin RPC, Bohlmann J: Functional plasticity of paralogous diterpene synthases involved in conifer defense. Proc Nat Acad Sci USA 2008, 105:1085-1090.
57. Bohlmann J, Phillips M, Ramachandiran V, Katoh S, Croteau R: cDNA cloning, characterization, and functional expression of four new monoterpene synthase members of the tpsd gene family from grand fir (Abies grandis). Arch Biochem Biophys 1999, 368:232-243.

58. Katoh S, Hyatt D, Croteau R: Altering product outcome in Abies grandis (-)-limonene synthase and (-)-limonene/(-)-a-pinene synthase by domain swapping and directed mutagenesis. Arch Biochem Biophys 2004, 425:65-76.

59. Hyatt DC, Croteau R: Mutational analysis of a monoterpene synthase reaction: Altered catalysis through directed mutagenesis of (-)-pinene synthase from Abies grandis. Arch Biochem Biophys 2005, 439:222-233.

60. Kolosova N, Miller B, Ralph S, Ellis BE, Douglas C, Ritland K, Bohlmann J: Isolation of high-quality RNA from gymnosperm and angiosperm trees. Biotechniques 2004, 36:821-824.

61. Pavy N, Boyle B, Nelson C, Paule C, Giguere I, Caron S, Parsons LS, Dallaire N, Bedon F, Berube H, Cooke J, Mackay J: Identification of conserved core xylem gene sets: Conifer cDNA microarray development, transcript profiling and computational analyses. New Phytol 2008, 180:766-786.

62. De la Bastide M, McCombie WR: Assembling Genomic DNA Sequences with PHRAP, Current Protocols in Bioinformatics. Wiley OnlineLibrary: Wiley and Sons; 2007. Chapter 11 Unit 11.4.

63. O'Maille PE, Chappell J, Noel JP: A single-vial analytical and quantitative gas chromatography-mass spectrometry assay for terpene synthases. Anal Biochem 2004, 335:210-217.

doi:10.1186/1471-2229-13-80

Cite this article as: Hall et al:: Transcriptome resources and functional characterization of monoterpene synthases for two host species of the mountain pine beetle, lodgepole pine (Pinus contorta) and jack pine (Pinus banksiana). BMC Plant Biology 2013 13:80.

\section{Submit your next manuscript to BioMed Central and take full advantage of:}

- Convenient online submission

- Thorough peer review

- No space constraints or color figure charges

- Immediate publication on acceptance

- Inclusion in PubMed, CAS, Scopus and Google Scholar

- Research which is freely available for redistribution

Submit your manuscript at www.biomedcentral.com/submit
C) Biomed Central 